\title{
Assessment of Individual Household Waste Generation Quantity in Different Areas of Salem
}

\author{
U. Indirapriyadharshini, M. Adhiyaman, R. Santhosh Kumar and S. Venkatesan
}

\begin{abstract}
Around the world as countries are struggling to arrive at an effective regulatory regime to manage the Municipal Solid Waste of Individual Household into their ecosystem. Considering that Individual Household comply with environmental regulations based on the level of enforcement and their ability to spend for Municipal Solid Waste Management, this project endeavours to sketch probable Municipal Solid Waste Management scenarios under various market-enforcement conditions and proposes possible strategies for effective regulatory regime in Salem. A manual survey was conducted through a questionnaire in 15 different areas of Salem district representing different taluks of Salem to account the primary household waste disposal strategy. A structured questionnaire is prepared which interrogates about types of waste generated, amount of waste generated in a home per day and disposal methods, whether compost pit exist or not. In all the 15 areas at different locations around a sample 10 houses were surveyed. The collected data were analyzed thoroughly and profound existing strategies in all the 15 places were found out. This survey is taken for 15 different areas of Salem which are Pannangkattur, R.E.Quarters, Neethipuram, K.Pudur, Sauripalayam, Avarangapalayam, Kannangkurichi, Mullaivadi, Allikuttai, Suramangalam, Udayapatti, Alagapuram, Shevapet, Jagairammapalayam and Narayanapuram.
\end{abstract}

Index Term--- Manual Survey, Structured Questionnaire, Surveyed Places, Quantity of Waste Generated

\section{INTRODUCTION}

$\mathrm{S}_{1}^{\mathrm{A}}$ ALEM is located in the southern part of India at $11.669427^{\circ} \mathrm{N} .140865^{\circ} \mathrm{E}$ at an average elevation of $278 \mathrm{~m}$ (912ft). Salem is located about 340 kilometers (210 miles) southwest of Tamil Nadu.

Salem is one of the municipal corporations and the fifth largest city in Tamil Nadu in terms of population. The area of Salem City is 134 Sq.km. 829,267 is the present population of Salem City.

With such a vast land area population, it is becoming tougher to provide basic facilities in hygienic manner to people and also Environmental issues in Salem Corporation

U. Indirapriyadharshini, Department of Civil Engineering, Sona College of Technology, Salem. E-mail:indu_amul@yahoo.co.in

M. Adhiyaman, Department of Civil Engineering, Sona College of Technology, Salem.E-mail:adhicivil@gmail.com

R. Santhosh Kumar, Department of Civil Engineering, Sona College of Technology, Salem.E-mail:santhoshbala146@gmail.com

S. Venkatesan, Department of Environmental Science, Periyar University, Salem.E-mailsvenkatesan75@gmail.com

DOI: 10.9756/BIJIEMS.7017 are getting increased day by day.

Around 350tonnes of Municipal Solid Waste is generated per day in Salem City.

\section{SALEM District}

Salem district has nine taluks. They are Mettur, Omalur, Salem, Attur, Edappadi, Sankari, Yercaud, Gangavalli, and Vazhapadi. Salem Municipal Corporation consists of 60 wards with an extent of $91.34 \mathrm{sq}$. km. Dumper bins are placed at suitable locations for collection of garbage. The garbage is collected and transported through the fleet of vehicles for disposal. Under the 60 wards around 21 divisions are privatized for primary collection and transportation of the garbage. The garbage is processed scientifically in the newly constructed, solid waste processing plant on BOOT basis in Chettichavadi as per the Solid waste management rules, 2000.

About 350 tones of wastes generated by the Salem City Municipal Corporation every day is being processed and converted into reusable materials. The processes involved in waste management are Tipping, Auto segregation, Separate processing of materials (Refused derived fuel, Remoulded plastics, Bio-composting), Sanitary land filling.

The existing solid waste management system in Salem serves as an example of steer solid waste management system in a technical manner.

The concept of solid waste management should originate truly right from the point of waste generation. To encounter the waste generation and disposal strategy we went on to a manual survey to different places of Salem with the questionnaire.

The questionnaire reveals information about generation and disposal strategy in different parts of Salem. The survey is conducted in 15 different places of Salem to know the primary household waste disposal strategy. The rate of waste generation varies from area to area and based on population, standard of living etc.,

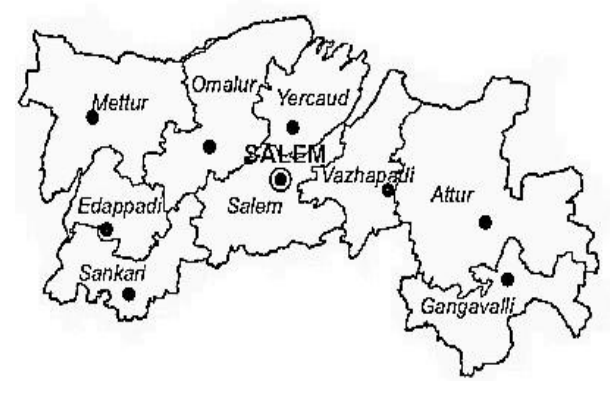

Fig. 1: Salem Taluk Map 


\section{METHODOLOGY}

\section{Manual Survey}

A manual survey was conducted through a questionnaire in 15 different areas of Salem district representing different taluks of Salem to account the primary household waste disposal strategy. In all the 15 areas at different locations around a sample 10 houses were surveyed. The collected data was analyzed thoroughly and profound existing strategies in all the 15 places were found out.

\section{Questionnaire}

Present Disposal and Management of Solid Waste Strategy in Rural Areas of Salem

Taluk:

Name of the village:

Name of the resident:

Number of persons in your home:

Address:

Amount of waste generated per day in your home:

Solid waste $(\mathrm{kg})$

Types of solid waste

Disposal strategy:

Incineration/Burying/Dumping/Composting

Whether compost pit exist or not - yes or no

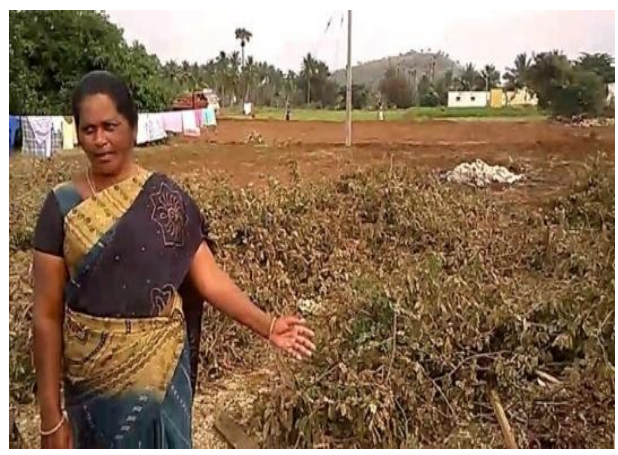

Fig. 2: Compost Pits in Omalur

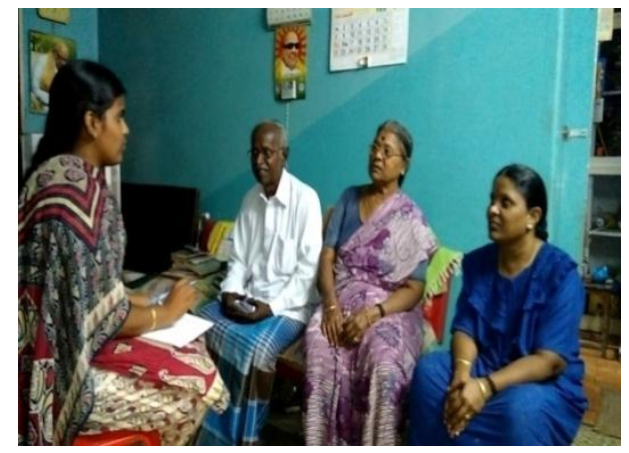

Fig. 3: Survey in Suramangalam

\section{Individual Household Waste Generation Quantity Calculation}

Calculation of Average Waste Generation in an Area: (Direct Reply from the Residents)

Quantity of solid waste generated in their home every day was accounted in $(\mathrm{Kg}) / 10$

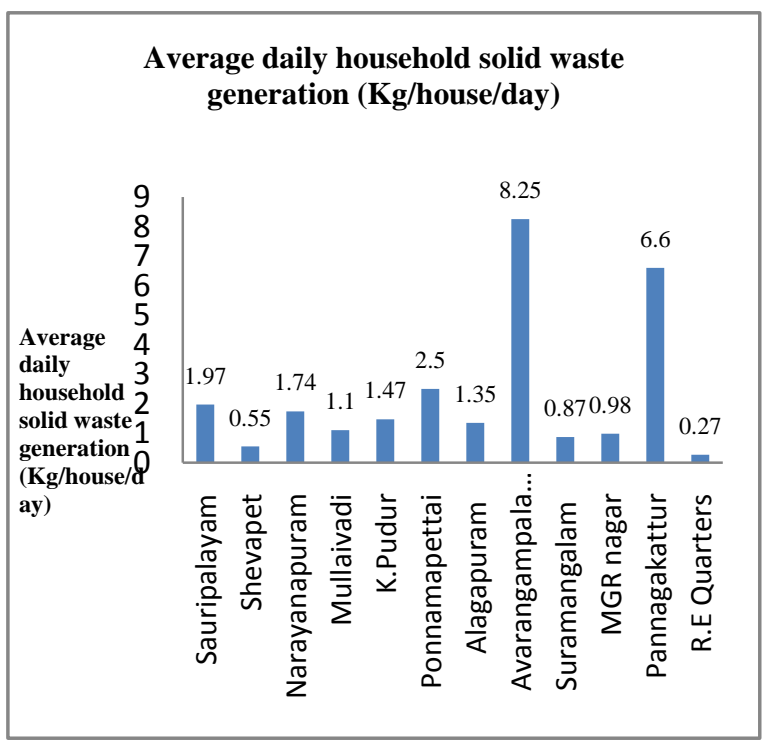

Fig. 4: Average Daily Household Solid Waste Generation (Kg/house/day)

Calculation of Per Capita Solid Waste Generation Per Day: (Direct Reply from the Residents)

Quantity of waste generated per day in individual home / No. of persons in their home.

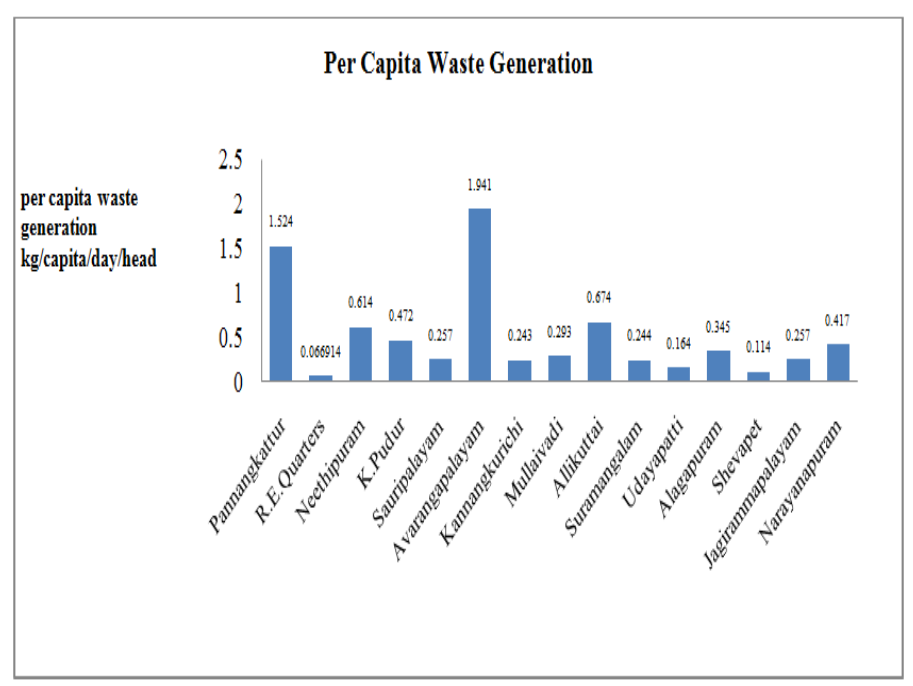

Fig. 5: Per Capita Waste Generation kg/capita/day/head 
Calculation of Average Per Capita Demand in an Area

Sum of per capita solid waste generation/10.

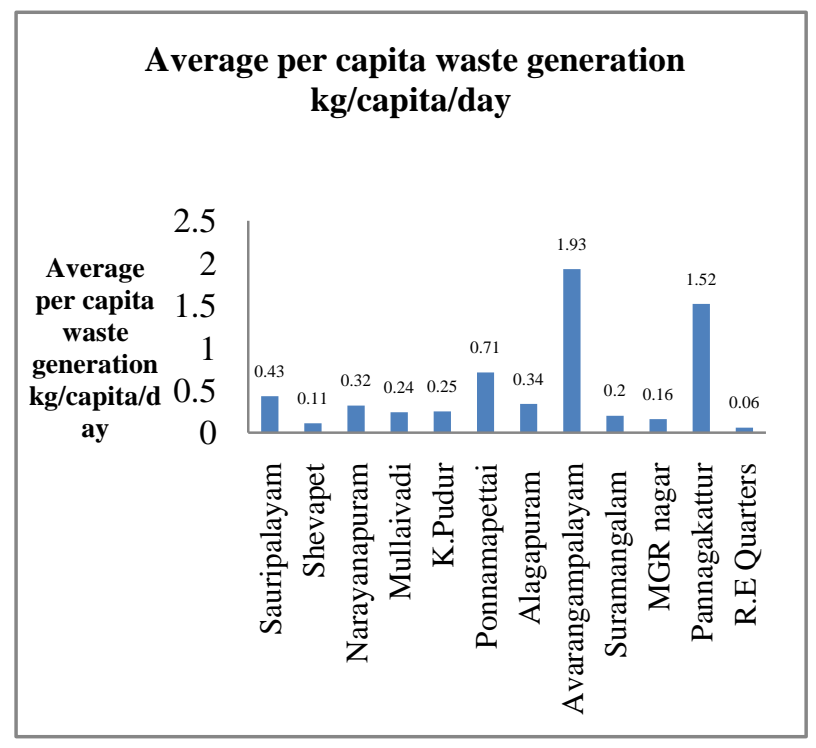

Fig. 6: Average Per Capita Waste Generation kg/capita/day

\section{RESULTS \& DISCUSSION}

Types of waste: Direct reply from the residents regarding the different types of solid waste arising out daily from their home is accounted.

The Average Daily Household Solid Waste Generation in Salem (including all the considered places) is 2.30 $\mathrm{kg} / \mathrm{house} / \mathrm{day}$.

The Per Capita Waste generation in Salem (including all the considered places) is $0.505 \mathrm{~kg} / \mathrm{house} / \mathrm{day} / \mathrm{head}$.

The average per capita solid waste generation in Salem (including all the considered places) is $0.7611 \mathrm{~kg} /$ house/day.

Name of the Places where Survey is Conducted

Table 1: Surveyed Places

\begin{tabular}{|l|l|l|}
\hline S.NO & TALUK & AREA \\
\hline 1 & Omalur & Pannangkattur \\
\hline 2 & Mettur & $\begin{array}{l}\text { R.E.Quarters } \\
\text { Neethipuram }\end{array}$ \\
\hline 3 & Edappadi & $\begin{array}{l}\text { K.Pudur } \\
\text { Sauripalayam }\end{array}$ \\
\hline 4 & Sankari & Avarangapalayam \\
\hline 5 & Yercaud & Kannangkurichi \\
\hline 7 & Salem & $\begin{array}{l}\text { Allikuttai } \\
\text { Suramangalam } \\
\text { Udayapatti } \\
\text { Alagapuram } \\
\text { Shevapet } \\
\text { Jagairammapalayam }\end{array}$ \\
\hline 8 & Gangavalli & Narayanapuram \\
\hline
\end{tabular}

\section{CONCLUSION}

The results of this study show that it is feasible to provide proper Solid waste disposal techniques to control the environmental degradation. The prediction we made from the above analysis is the individual household per capita municipal solid waste generation quantity in different areas of
Salem has been determined analytically with the help of manual survey. Out of 15 places Avarangapalayam (Sankari Taluk) and Pannangkattur (Omalur Taluk) is the areas maximum amount of municipal solid waste generated. There are different policies like rapid composting, recycling machine, and treatment plant. If these techniques are properly implemented and managed then the negative impacts due to waste generation can be considerably reduced. If these techniques integrated to the whole Salem district, then the future development of Salem as a metropolitan city will cause very minor effect to the environment and tends to be a safest development unlike other metropolitans.

\section{REFERENCE}

[1] A. D. Bhide, and B.B.Sundaresan, "Solid Waste Management in Developing Countries", New Delhi, India: Indian National Scientific Documentation Center, 1983

[2] RV Bhoyar, SK Titus, AD Bhide, P. Khanna, "Municipal and industrial Solid Waste Management in India", J Indian Assoc Environ Management 23, Pp:53-64, 1996.

[3] Boyle C.A, Solid Waste Management in New Zealand. Waste Management, 20, Issue: 7, Pp:517-526, 2000.

[4] Central Pollution Control Board (CPCB), "Collection, Transportation and Disposal of Municipal Solid Waste in Delhi (India) a case study", Central Pollution Control Board, Delhi, 1998.

[5] 21st edition, "American public health association Washington D.C., APHA, "Standard methods for examination of water and waste water", 2005.

[6] Baccini, P. (Ed) springer verlag berlin Pp.399 (1989) Arneth, J.D., Midle, G., Kerndoff, H. and schleger, R., "Waste in deposits influence on ground water quality as a tool for waste type and site selection for fnal storage quality"

[7] S. Murugavelh and Vinoth Kumar, "Removal of heavy metal from waste water using different biosorbents. Current world environment", 5(2), Pp:299-304, 2010

[8] Nolan, K., "Copper toxicity syndrome. Journal of orthomolecular psychiatry", 12, Pp:270-282, 2003.

[9] uttar Pradesh, india, current science, 96(7), 979-985 Raju .N Janardana, Dey Sangita and Das Kasushik, "Fluoride contamination in ground water of sonbhadra district"

[10] Sahni Anirudh. and Gautam Abhishek satus of pre-monsoon "Ground water quality near municipal solid waste dumping site of jaipure with respect to chlorides, nitrates", 2009

[11] WHO, GENEVA, "Guidelines for drinking warer quality second edition. Vol 2 health criteria and other supporting information", 1996.

[12] earthquake publishing, (1992) Zenglu xia, "Soil environmental capacity of china"

[13] Bruins M R, Kapil s and O EHME FW, "ecotox environ safe", 45, Pp:198-207, 2000.

[14] "Personality, individual differences, and demographic antecedents of self-reported household waste management behaviors", Journal of environmental psychology, March 2011.

[15] Er. Amit Bijon Dutta Senior Manager, Mecgale Pneumatics Private Limited, N65, Hingna MIDC, Nagpur 440016 "Review of solid waste management in india"

[16] "Solid waste management practices and review of recovery and recycling operations in Turkey", Waste Management, 23, Pp:425-432, 2003

[17] "Municipal solid waste management in Indian cities - A review", Waste Management, 28, Pp: 459-467, 2008.

[18] Environmental and resource economics, "Household Waste Management in a Swedish Municipality: Determinants of Waste Disposal, Recycling and Composting", February 1999.

[19] T. Subramani, "Identification and Investigation of Solid Waste Dump in Salem District" et al. Int. Journal of Engineering Research and Applications www.ijera.com ISSN:2248-9622, Vol. 4, Issue 12( Part 5), Pp.88-99, December 2014. 